\title{
THE ANALYSIS OF THE CHOSEN INTERNAL CONDITION AND PROSPECTS OF ROMANIA'S ENERGY SECURITY
}

\author{
Michał RUTKA \\ Jagiellonian University in Cracow, Poland \\ micha.rutka@gmail.com
}

\begin{abstract}
In the age of high pace of technological, economic and social development, stable and uninterrupted energy supply is one of the key components determining the economic sovereignty of the state, its position in international relations, and the quality of human life. Every economy around the world is heavily dependent on its energy sector. Consequently, ensuring energy security is currently one of the most important determinant of every country's national security and the purpose of its security policy. In this article we focus on Romania's energy security internal condition and prospects. Our main goal is to present actual state and prospects of Romanian energy sector. In order to achieve that goal, we decided to use various methods, such as descriptive analysis, document analysis and comparative analysis. The article has two parts. The first part consists of a description of energy sources and infrastructure used by Romanian economy. The second part is an analysis of possible chances and threats for both energy sector and energy security level.
\end{abstract}

KEYWORDS: energy, energy security, prospects, resources, Romania

\section{Introduction}

Romania, a country located at the crossing point between east-west and northsouth energy transit routes, is in relatively privileged position compared to other countries in Central and Eastern Europe. It is because of its strategic position, reasonably well-balanced mix of primary energy resources and relatively low dependency on imported resources. Taking into account these factors, Romania is currently the third most energy-independent country in the European Union, with roughly $21 \%$ independency rate (Sobják, 2013, p. 1).
This situation prompted us to undertake an analysis of the chosen internal conditions of the Romanian energy security, as well as the analysis of its possible prospects for the future. In order to fully understand the analyzed issues, we must state what is the definition of energy security. Although there are many different definitions of this term, we decided to present the one, which is given by the International Energy Agency. The IEA defines energy security as "the uninterrupted availability of energy sources at an affordable price. Energy security has many aspects: long-term energy security mainly deals with timely investments to supply 
energy in line with economic developments and environmental needs. On the other hand, short-term energy security focuses on the ability of the energy system to react promptly to sudden changes in the supply-demand balance" (Gatej et al., 2016, p. 3).

As we can see, energy security is a very complex term which is associated with many issues. In order to analyze the topics of this article, we decided to describe the current state of production, consumption, reserves and possible level of import of the most important energy sources in Romania. The second part of this article comprises a description of possible prospects for the Romanian energy security (threats and chances).

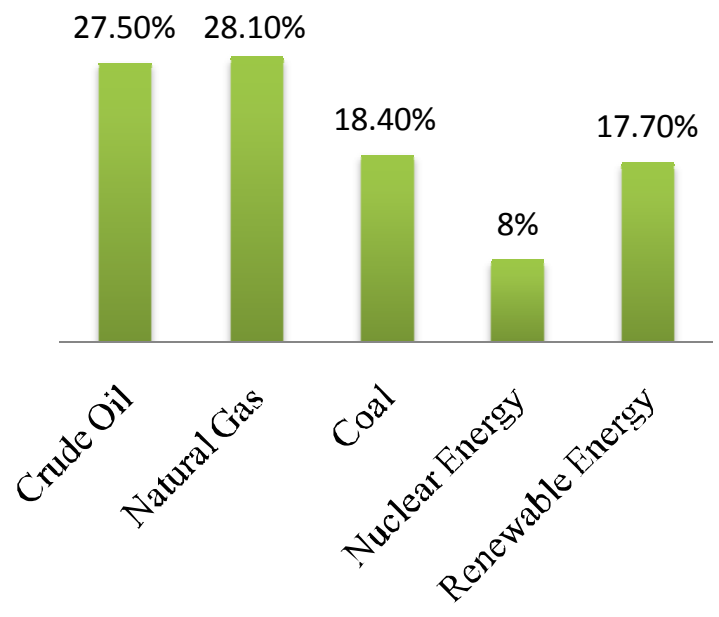

\section{Chart no. 1 Romanian primary energy consumption by energy source in 2015}

\section{Crude Oil}

In today's world the crude oil is probably the most important energy resource because of its utility for petrochemical industry, which uses crude oil to get gasoline, kerosene, oil, wax, grease, asphalt, petroleum residue, petroleum jelly and many synthetic materials. Thus, it would be no exaggeration to say that the availability of crude oil determines the development of the entire global economy.

Also for Romania this resource is an important element of the national energy system - it covers approximately $27.5 \%$ of the Romanian energy demand. According to international reports, in 2015 Romania used 9.1 million tonnes of crude oil. This is a considerable decrease compared with 2007, in which the average consumption was about 10.3 million tonnes of oil (Dudley et al., 2016, p. 11). This effect is the result of both the EU's energy-saving policy, which Romania has adopted together with joining the European Community in 2007, and the global economic crisis, which also affected Romania in 2007-2008 (Trușcă, 2015, p. 58).

Crude oil is extracted, among others in the region of Ploieşti (at the mouth of Prahova valley), in the Moldavian Subcarpathians in region of Trotus valley and nearby Bacău (Polish Embassy in Bucharest, 2015). With 10 working refineries and an overall refining capacity of approximately 80,100 cubic meters per day, Romania has the largest refining industry in the region. Though there is a natural decline in crude oil production, Romania continues to be the fourth largest oil producing country in the European Union, and fifth in Europe. Romania extracts almost 4 million tonnes of oil per year, however the production is not enough to cover all domestic demand. As a result, Romania is a net importer of crude oil 
(in 2014 imports accounted for $57 \%$ of domestic consumption). In 2014, the major suppliers of crude oil to Romania were Kazakhstan with $69 \%$ share and Russia with $28 \%$ share (The Observatory of Economic Complexity, 2014).

Proved oil reserves are approximately 100 million tonnes, enough to meet the needs of Romania for about 23 years. This is not a solid guarantee if we take into account the declining domestic production and rising dependence on the imported oil (Dudley et al., 2016, p. 6).

\section{Natural Gas}

Another important pillar of the Romanian energy is the natural gas. Its participation in the generation of energy for the whole country exceeds $28.1 \%$ making it the most important energy source of the Romanian economy. Statistics show, that consumption of natural gas in Romania is progressively declining - in 201212.4 billion cubic meters (bcm) of gas was used, while in 2015 it was already $10.3 \mathrm{bcm}$. This situation is favourable for the Romanian economy due to the fact, that domestic production has increased relative to 2014 by $5.4 \%$, reaching in $2015 \mathrm{a}$ level of $10.3 \mathrm{bcm}$ of gas (Dudley et al., 2016, pp. 20-23). This means, that in terms of demand for this raw material, Romania is almost completely (98\%) self-sufficient. As a result, imported gas covers only $2 \%$ of domestic consumption (Autoritatea Naţională de Reglementare în domeniul Energiei, 2016, p. 1).

Interestingly, the gas production in Romania could have reached larger size, if not the policy pursued by the communist government in the eighties of the last century, involving the maximum exploitation of domestic deposits, simultaneously eliminating imports. Excessive and uneven operation led to the impoverishment of deposits, that in turn greatly reduced the production potential of Romania, which despite having the second largest gas market in Central and Eastern Europe, still has to grapple with this problem. Currently, natural gas production is mainly carried out on the Transylvanian Plateau, near Mediaş and Saroş, and in the Carpathian region, namely in Suceava County (Polish Embassy in Bucharest, 2015). The gas transmission systems in Romania contains of 12,580 kilometres of pipelines which are operating at low pressure (Gatej et al., 2016, p. 19).

Proved reserves of natural gas Romania is estimated at about $100 \mathrm{bcm}$ which is sufficient to meet its needs for about 10-15 years. Although proven reserves are quickly depleted, there is a chance for obtaining this resource from another source - there are gas deposits under the Black Sea, whose resources are estimated at about $42-84 \mathrm{bcm}$. It is estimated that the start of gas production from these deposits could start at the end of this decade (Gatej et al., 2016, p. 18).

In addition, it is assumed that Romania has unrecognized deposits of shale gas. In 2012 the Romanian authorities decided to grant some concessions to foreign companies for the exploration of gas trapped in shale. These actions have not brought the expected results, while in 2015 the most important entity conducting the search - the US company Chevron (holding exploration licenses in the region of Dobrogea and Vaslui) - after several boreholes Chevron announced its decision to withdraw from the project for shale gas exploration in Romania. Any exploration of shale gas in this country is still an open question (Gatej et al., 2016, p. 18).

\section{Coal}

The third most important raw material of the Romanian energy is coal, whose production for industrial purposes started in the area of present-day Romania, more than 150 years ago. Romanian hard coal and lignite output is mainly used for power generation and heat. Though in recent years the production of coal had a decreasing trend, Romania ranks seventh among coal 
producers in the European Union member countries (Stanciu, 2015).

The share of coal (both hard coal and lignite) in the production of energy in 2015 accounted for approximately $18.4 \%$ of the total energy balance. This means that last year's coal consumption in Romania stood at about 6.1 million tonnes of oil equivalent (toe). It is very interesting that despite the declared desire to move away from the use of coal in favour of renewable energy sources, Romania increased its use by almost $7 \%$ compared to 2014. A similar trend is observed in production of this raw material - in 2015 it corresponded to 4.8 million toe, so it is a growth of more than $8.4 \%$ compared to 2014 (Dudley et al., 2016, pp. 32-33).

While the lignite mining as a whole covers the demand for this type of coal, hard coal production is insufficient and therefore it is necessary to import it from abroad (1 million toe (Brown et al, 2015, p. 122). At present, Romania has four working hard coal underground mines and two lignite mines. Coal mining is conducted mainly in the upper valley of the river Jiu (around Petroşani, Vulcan and Lupeni). Lignite is mined in the southern part of the Carpathians, in areas of Ploieşti and Oltenia (Eurocoal).

Proved reserves of coal are estimated to be about 291 million tonnes (10 million tonnes of hard coal and 281 million tonnes of lignite), which compared to other similar-area countries of the European Union, is not a large quantity. It should however be borne in mind, that if Romania maintain the current level of consumption of coal, its reserves will suffice to cover Romania's need for about 45 years (Dudley et al., 2016, pp. 32-33).

The current EU laws on environmental protection oblige the coal industry to meet several European standards which necessitates large investments. According to the EU directives, 78 large combustion plants need to comply with stricter environmental requirements by
2017 (Eurocoal). Currently, the Romanian authorities are in the process of implementing the plan approved by the European Commission concerning the closure or restructuring of the remaining active coal mine. It is necessary if Romania is to maintain the important role of fossil fuels in primary energy generation (Eurocoal). So far, Romania has decided to close three hard coal mines deemed unprofitable. Petrila mine was closed at the end of October 2015 after 156 years of operation; the other two - Uricani and Paroşeni - shall be closed until the end of 2017 (Polish Embassy in Bucharest, 2015).

\section{Nuclear Energy}

In addition to the use of the conventional energy sources, Romania also benefits from the usage of alternative sources such as nuclear energy. Romania has only one nuclear power plant located in Cernavoda. The first reactor began to work in 1996, and the second one 11 years later. In the near future, it is planned to launch two additional nuclear reactors in Cernavoda nuclear power plant (World Nuclear Association).

State-owned company Compania Nationala a Uraniului produces an annual average of 50 tonnes of uranium from proven reserves of this raw material located in the north of the country in Crucea-Botusana. Production is partly subsidized by the government of Romania. In 2015, uranium production was exceptionally 77 tonnes. Used nuclear fuel is stored for 6 to 10 years in the same reactor, and then is transferred to the storage of dry waste, which is also located in Cerrnavoda. In store this waste will be held for the next 50 years under the strict supervision of nuclear power plant's management (World Nuclear Association).

The two currently operating reactors generate energy, which in 2015 covered $8 \%$ of the total energy demand of Romania. This means that last year the value of the used energy coming from 
active reactors was approximately 2.6 million tonnes (Dudley et al., 2016, p. 35).

Despite the relatively small share of nuclear power in the overall energy balance of Romania, there are indications that over the next several years, that source of energy will be one of the main pillars supporting the Romanian economy (World Nuclear Association). That can be expected for two reasons: the first is the already mentioned plan of increasing the number of active reactors, and the second is the low price of energy from nuclear power plant (only energy produced in hydroelectric plants is cheaper).

\section{Renewable Energy}

The above described sources of energy belong to the non-renewable sources, which means that their further exploitation will result in depletion of deposits in short or longer term. Nowadays, modern countries are trying to avoid the situation when the whole economy is based only on non-renewable sources. In order to achieve that goal, many countries are developing new technologies that allow them to use energy from renewable sources. The advantage of using renewable energy sources is also a lack of (or a small amount of) emissions of harmful chemicals during the production of energy.

Like many other countries, Romania is also investing in development and implementation of technologies for exploiting renewable energy sources. An important factor that accelerates these processes is the environmental policies of the European Union aiming at reducing emissions of harmful substances from the processing of traditional energy sources such as oil, gas or coal. The energy in Romania is obtained from several renewable sources such as water, wind, sun, and biomass (Gatej et al., 2016, p. 3).

The total share of these sources in the generation of energy in Romania in 2015 amounted to more than $17.7 \%$, which means that about 5.9 million toe had been produced.
The share of each of these sources in the total energy consumption coming from renewable energy sources is as follows: water $-63 \%$, sun $-7 \%$, wind $-27 \%$, biomass in general (wood, bio-fuel, waste) - $3 \%$ (Dudley et al., 2016, pp. 36-38). Production of energy from renewable sources is increasing each year, indicating that Romanians seriously approach the issue of use this type of energy. This is a favourable situation because of the depletion of resources traditionally used in the process of obtaining energy.

The dynamic development of renewables which takes place in Romania will have a positive impact on the overall level of energy security of the country. Also, it cannot be forgotten, that the intensive development of renewable energy sources in Romania is dictated not only by the desire to increase the level of independence and energy security of the country, but also by requirements of the European Union. The purpose of these requirements is to achieve $24 \%$ share of energy from renewable energy sources in the overall energy balance by 2020 . Analyzing the statistics, it can be concluded that Romania is on the good track to completing objectives of the EU in terms of renewable energy sources (Batóg, 2011).

\section{Prospects - Threats and Chances}

Presently, Romanian energy sector faces many serious threats which already have or might have highly negative consequences for the level of energy security and thus, for the security of the Romania itself. Some of the threats come from the weakness and vulnerabilities of the energy system, the others come from the characteristic of the international markets and policies. That is why we decided to present the most significant threats for the Romanian energy security which are foreseen by the experts:

> Projected exhaustion of crude oil, natural gas and coal. Assuming that the Romanian energy consumption maintain its current level over the next few years, we 
should expect a significant increase in dependence on foreign supplies of required energy resources. It is estimated that by the end of the second decade of this century, increasing share of imported raw materials in the energy balance of Romania will become apparent (Gatej et al., p. 4).

$>$ The risk of blackout, which might be caused by physically worn-out and mortally obsolete energy transport infrastructure (pipelines, high-voltage lines etc.), outdated and ineffective power production facilities (mainly associated with hard coal (Gatej et al., p. 5)).

$>$ Economic and financial crises, the occurrence of which is practically impossible to predict. In the case of a worldwide crisis, Romania has little chance of avoiding its possible consequences, which is confirmed by statistics from the period of the global economic crisis which started in 2008 (Dudley et al., 2016, pp. 36-38).

$>$ Further creating inconsistent, inadequate and unpredictable laws and regulation which are going to discourage and hinder potential domestic and international partners from investing in the Romanian energy sector (Sobják, 2013, p. 2).

Besides various threats, the energy sector of Romania faces many various opportunities, which properly used, can positively affect both the development of the energy sector, and raise of the level of its security. According to many experts and think-tanks, Romania will face considerable challenges in the energy sector in the future. In order to deal with challenges and threats in short and long term, it seems necessary for Romania to use the opportunities that arise. At present, mainly considered chances are as follow:

$>$ Increasing the expenditures for research that could affect the development of new technologies to increase the efficiency of energy production, or to discover new deposits of strategic raw materials. Investment in research, might also contribute to reduction of the energy intensity of the economy and to increase the level of environmental protection. Research institutions have a major impact on broadening the perspectives and possibilities of development of the Romanian energy sector, so it seems reasonable to increase the outlays earmarked for higher education, which will provide skilled scientific staff in the future (Duduială, 2015, p. 141).

$>$ Application of modern technologies in power generation and use with proper regard for environmental concerns and development of alternative or unconventional sources of energy to reduce the cost of electricity. It should be a part of general modernization of the whole energy sector (Gatej et al., p. 5).

$>$ Further liberalization and integration of domestic energy market combined with simple and encouraging regulation system, which would create a proper environment for potential investors, producers and customers (Sobják, 2013, p. 2).

> The opportunity to undertake a more complex cooperation with foreign partners in the field of energy. With the new projects of international pipelines, interconnectors, power plants and energy storage, the Romanian energy sector would gain new opportunities for development and increase the level of their security. These include new directions for diversification of imported crude oil and natural gas. It would allow Romania to be less reliant on supplies from Russia and Kazakhstan (Gatej et al., pp. 5-6).

\section{Conclusion}

The above-mentioned prospects as well as the current condition of energy sources issues give us an approximate view of the actual state of the Romanian energy sector and its level of energy security. From this point of view, it seems that the current state of the Romanian energy sector is not fully satisfactory. Various structural, political and technological problems make the Romanian energy security not be at a high level. It should take a lot of action and 
corrective measures to overcome the most serious drawbacks and avoid the threats that might appear on the path of stable development of the Romanian energy sector.

However, we cannot ignore the important issues relating to the current level of energy independence of the country. Despite the rather negative forecasts on exhaustible deposits and increasing imports, Romania still has one of the biggest indicators of energy independence across the European Union. A balanced and diversified structure of energy production is relatively good starting position for the further development of the energy sector. Another conclusion to be drawn after this analysis is that Romania should be more intensively involved in international cooperation, as foreign partners have much to offer to the Romanian energy sector. The benefits of international co-operation might be various: increase of the potential for domestic energy production, development of critical infrastructure, favourable conditions for the import of scarce resources, or increase of international importance of Romania. In view of the challenges facing the Romanian energy sector today, it seems reasonable not to reject the opportunities and the possibilities offered by the cooperation at international level.

Despite several significant advantages and strengths, the Romanian energy sector still faces many problems that restrict its development and functioning. It seems, however, that through the implementation of a comprehensive system of actions by government authorities, and thanks to the use of available opportunities and chances for development, the level of energy security of Romania will rise.

\section{REFERENCES}

Autoritatea Naţională de Reglementare în domeniul Energiei. (2016). Tipul surselor de gaze naturale în anul 2015, available at: http://www.anre.ro/download.php? $\mathrm{f}=$ gqp $7 \mathrm{iQ} \%$ 3D\%3D\&t=vdeyut7dlcecrLbbvbY\%3D.

Batóg, P. (2011). Turbiny wiatrowe GE $w$ Rumunii, available at:

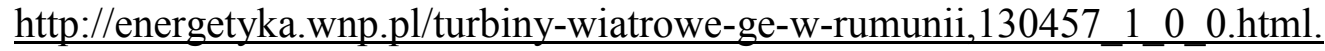

Dudley, B. et al. (2016). BP Statistical Review of World Energy 2016, available at: https://www.bp.com/content/dam/bp/pdf/energy-economics/statistical-review-2016/bpstatistical-review-of-world-energy-2016-full-report.pdf.

Duduială, L. (2015). The Romanian energy strategy for 2014-2020. Târgu-Jiu: Annals of the Constantin Brâncuşi University, no. 5, 137-141.

Embassy of Republic of Poland in Bucharest. (2016). Gospodarka rumuńska, available at: http://www.bukareszt.msz.gov.pl/pl/wspolpraca dwustronna/gospodarka rumunska/.

Euracoal. (2016). Romania, available at: https://euracoal.eu/info/countryprofiles/romania.

Gatej, A. et al. (2016). Romanian's Energy Crossroads. Washington: Center for European Policy Analysis

Sobják, A. (2013). Szanse na integrację regionalną rumuńskiego rynku gazu. Bulletin of the Polish Institute of International Affairs, no. 37, 1-2.

Stanciu, O. (2015). Romanian coal mining industry, available at: http://visegradplus.org/analyse/ romanian-coal-mining-industry/

Trușcă, I. (2015). Romania's National Energy Security Strategy in the Europa 2020 Strategy. Agora Alumni, no. 2, 49-63.

The Observatory of Economic Complexity, available at: http://atlas.media.mit.edu/en/visualize/ tree map/hs92/import/rou/show/2709/2014/

World Nuclear Association. Nuclear Power in Romania, available at: http://www.world-nuclear.org/information-library/country-profiles/countries-os/romania.aspx. 